\title{
Bifidobacterium bombi sp. nov., from the bumblebee digestive tract
}

\author{
J. Killer, ${ }^{1,2}$ J. Kopečný, ${ }^{2}$ J. Mrázek, ${ }^{2}$ V. Rada, ${ }^{1}$ O. Benada, ${ }^{3}$ I. Koppová, ${ }^{2}$ \\ J. Havlík ${ }^{1}$ and J. Straka ${ }^{4}$ \\ ${ }^{1}$ Czech University of Life Sciences, Department of Microbiology, Nutrition and Dietetics, Kamýcká \\ 129, Prague 6 - Suchdol, 165 21, Czech Republic \\ ${ }^{2}$ Institute of Animal Physiology and Genetics v.v.i., Academy of Sciences of the Czech Republic, \\ Vídeňská 1083, Prague 4 - Krč, 142 20, Czech Republic \\ ${ }^{3}$ Institute of Microbiology v.v.i., Academy of Sciences of the Czech Republic, Vídeňská 1083, Prague \\ 4 - Krč, 142 20, Czech Republic \\ ${ }^{4}$ Charles University in Prague, Department of Zoology, Albertov 6, Prague 2, 128 43, Czech \\ Republic
}

Correspondence

J. Kopečný

kopecnyj@iapg.cas.cz

\begin{abstract}
Gram-positive-staining, anaerobic, non-spore-forming, lactate- and acetate-producing bacterial strains were isolated from the digestive tracts of different bumblebee species (Bombus lucorum, Bombus pascuorum and Bombus lapidarius). All of the isolates produced fructose-6-phosphate phosphoketolase activity. A representative strain, $\mathrm{BluCl} / \mathrm{TP}^{\top}$, was characterized further. Cells of strain $\mathrm{BluCl} / \mathrm{TP}^{\top}$ showed occasional bifurcation and irregular constrictions. The bacterium utilized a wide range of carbohydrates. Glucose was fermented to acetate and lactate. The DNA base composition was $47.2 \mathrm{~mol} \% \mathrm{G}+\mathrm{C}$. Complete $16 \mathrm{~S}$ rRNA and partial $h s p 60$ gene sequences were obtained and phylogenetic relationships were determined. Strain BluCl/TP ${ }^{\top}$ and related isolates were located in the actinobacterial cluster and were closely related to the genera Bifidobacterium, Scardovia, Aeriscardovia and Parascardovia. The results presented support the proposal of a novel species to accommodate strain $\mathrm{BluCl} / \mathrm{TP}^{\top}$, with the name Bifidobacterium bombi sp. nov.; the type strain is BluCl/TP ${ }^{\top}\left(=\mathrm{DSM} 19703^{\top}=\right.$ ATCC BAA-1567 $\left.^{\top}\right)$.
\end{abstract}

Bumblebees are social insects that live in nests or colonies. Adults are represented by workers, which are sterile females, queens and males (drones), which come from unfertilized eggs and usually appear in late summer. The nest temperature is regulated to about $30{ }^{\circ} \mathrm{C}$. Each worker forages independently, and bumblebees never exchange food. These facts can influence the structure and metabolism of the bumblebee gut microbial population (Mohr \& Tebbe, 2006). These authors compared gut bacteria from Apis mellifera subsp. carnica (Carniolan honeybee) and Bombus terrestris (buff-tailed bumblebee), as well as from larvae of Osmia bicornis (red mason bee). The microflora was dominated by members of the Alphaproteobacteria, Betaproteobacteria, Gammaproteobacteria, Bacteroidetes, Firmicutes and Actinobacteria in all bee species. Bacterial cell densities were in the range $10^{8}-10^{9}$ cells per g gut contents, and the gut bacteria of adult bees were more diverse than in larvae.

The GenBank/EMBL/DDBJ accession numbers for the $16 \mathrm{~S}$ rRNA and partial $h s p 60$ gene sequences of strain $\mathrm{BluCl} / \mathrm{TP}^{\top}$ are EU127549 and EU869281.
The counts of anaerobic bacteria in honeybees were higher than the counts of aerobic species (Kačániová et al., 2004). The dominant bacteria in honeybee intestines were species of the genus Bacillus (Gilliam, 1997). Propionibacterium acnes was found in larvae of Apis mellifera and Osmia bicornis (Mohr \& Tebbe, 2006). This species was also very common in this study in the bumblebee digestive tract (not shown). Three bifidobacterial species have already been described from the honeybee digestive tract: Bifidobacterium asteroides, Bifidobacterium coryneforme and Bifidobacterium indicum (Felis \& Dellaglio, 2007). Because there were no reports on the presence of bifidobacteria in the bumblebee, the aim of this study was to describe the bifidobacterial population in the bumblebee digestive tract.

Bacteria were isolated from the digestive tracts of the bumblebee species Bombus lucorum, Bombus pascuorum and Bombus lapidarius. Worker bumblebees were collected in central Bohemia during summer 2006, and their intestinal tracts were weighed and transferred aseptically into tubes containing sterile MRS broth (Oxoid) supplemented with soybean peptone $\left(5 \mathrm{~g} \mathrm{l}^{-1}\right)$ and cysteine hydrochloride $\left(0.5 \mathrm{~g} \mathrm{l}^{-1}\right)$. The tubes were flushed with $\mathrm{O}_{2^{-}}$ 
free $\mathrm{CO}_{2}$ and closed with rubber stoppers. The same broth was used for serial dilutions of all samples. Aliquots $(0.1 \mathrm{ml})$ were plated on TPY agar with mupirocine as described by Rada \& Petr (2000). Propionibacterium acnes and representatives of several novel species with relatively low levels of $16 \mathrm{~S}$ rRNA gene sequence similarity (92-95\%) to the genus Bifidobacterium were present in the cultures.

Estimation of the $\mathrm{G}+\mathrm{C}$ content in bacterial chromosomal DNA was done after extraction and enzymic hydrolysis by HPLC chromatography on a C18 reversed-phase column (Supelcosil LC18) with the same guard column (Mesbah et al., 1989). DNA from Escherichia coli strain B (50 mol\%) and calf thymus (42 mol\%) was used as reference samples for $\mathrm{G}+\mathrm{C}$ content. The $\mathrm{G}+\mathrm{C}$ content of the representative strain BluCI/TP ${ }^{\mathrm{T}}$ was $47.2 \mathrm{~mol} \%$ (Table 1).

DNA of five strains was isolated (Gregg et al., 1994) and regions carrying the $16 \mathrm{~S}$ rRNA gene $(1490 \mathrm{bp})$ were amplified by PCR with the aid of primers $\mathrm{fD} 1$ and $\mathrm{rP} 2$ (Weisburg et al., 1991; Barcenilla et al., 2000) and then analysed by electrophoresis in $2 \%(\mathrm{w} / \mathrm{v})$ agarose gels (Sambrook et al., 1989). In three strains, 16S rRNA gene sequences were obtained after amplifying $500 \mathrm{bp}$ regions of bacterial DNA with primers FP27-515R, FP3-RP16 and FP19-rP2 (Forster et al., 1996). These fragments were sequenced on a 3100-Avant Genetic Analyzer (Applied Biosystems) with a BigDye Terminator v 3.1 cycle sequencing kit (Applied Biosystems). After editing, the full $16 \mathrm{~S}$ rRNA gene sequence was compared with published sequences of related bacteria from the EMBL and GenBank nucleotide databases using BLAST and with data from the Ribosomal Database Project (Maidak et al., 1994). The

Table 1. Characteristics of members of the genus Bifidobacterium isolated from the insect digestive tract

Strains: 1, strain BluCI/TP ${ }^{\mathrm{T}} ; 2$, B. asteroides DSM $20089^{\mathrm{T}} ; 3$, B. coryneforme DSM $20216^{\mathrm{T}} ; 4$, B. indicum DSM $20214^{\mathrm{T}}$. Some data for reference type strains were obtained from Simpson et al. (2004) and Huys et al. (2007). +, Positive; -, negative ; v, variable; ND, no data available. All taxa are positive for acid production from raffinose.

\begin{tabular}{|lcccc|}
\hline Characteristic & $\mathbf{1}$ & $\mathbf{2}$ & $\mathbf{3}$ & $\mathbf{4}$ \\
\hline $\begin{array}{l}\text { Temperature range for growth } \\
\left({ }^{\circ} \mathrm{C}\right)\end{array}$ & $10-37$ & $21-42$ & $\mathrm{ND}$ & $\mathrm{ND}$ \\
Acid from: & & & & \\
$\quad$ Arabinose & - & + & + & - \\
Cellobiose & - & + & + & + \\
Gluconate & - & $\mathrm{V}$ & + & + \\
Maltose & - & $\mathrm{V}$ & + & $\mathrm{V}$ \\
Mannose & + & $\mathrm{V}$ & - & - \\
Melezitose & + & - & - & $\mathrm{V}$ \\
Salicin & + & + & + & - \\
Sucrose & - & + & + & + \\
Trehalose & - & - & - & $\mathrm{V}$ \\
Xylose & - & + & + & - \\
DNA G+C content $(\mathrm{mol} \%)$ & 47 & 59 & 55 & 60 \\
\end{tabular}

sequences were aligned using CLUSTAL W (Thompson et al., 1994) in the BioEdit program (Hall, 1999). Nucleotide divergences among 16S rRNA gene sequences were calculated with the PAUP software, version $4.0 \mathrm{~b} 10$ (Swofford, 2003), using a corrected distance based on the GTR + I + G model of sequence evolution (Tavaré, 1986). The GTR + I+G model was determined to be the appropriate model for our dataset by the hierarchical likelihood ratio test of goodness-of-fit of 56 different nested models to the data, as implemented in the MODELTEST program, version 3.7 (Posada \& Crandall, 1998). Phylogenetic relationships among the sequences were reconstructed using PAUP by analysis of the distance matrix by the neighbour-joining algorithm and by using the maximum-parsimony (heuristic search) optimality criterion. Phylogenetic analyses using the maximumlikelihood criterion were performed with PAUP and using the GTR $+\mathrm{I}+\mathrm{G}$ evolutionary model with the following base frequencies: $A=0.2105, C=0.2350, G=0.3431$ and $T=0.2114$ (Fig. 1). To quantify the confidence in the partitioning within the maximum-likelihood tree, we performed the non-parametric bootstrap test as applied to phylogeny by Felsenstein (1985) using 1000 replications.

The highest 16S rRNA gene sequence similarity of isolate $\mathrm{BluCI} / \mathrm{TP}^{\mathrm{T}}$ was to $B$. asteroides CCUG $24607^{\mathrm{T}}$ (93\%). Because of the low $\mathrm{G}+\mathrm{C}$ content, the phylogenetic location of the novel strains was verified by another phylogenetic analysis. In this case, the hsp60 gene was selected and analysed with the same method, with the exception that the $\operatorname{TrN}+\mathrm{I}+\mathrm{G}$ evolutionary model was selected (Fig. 2). The

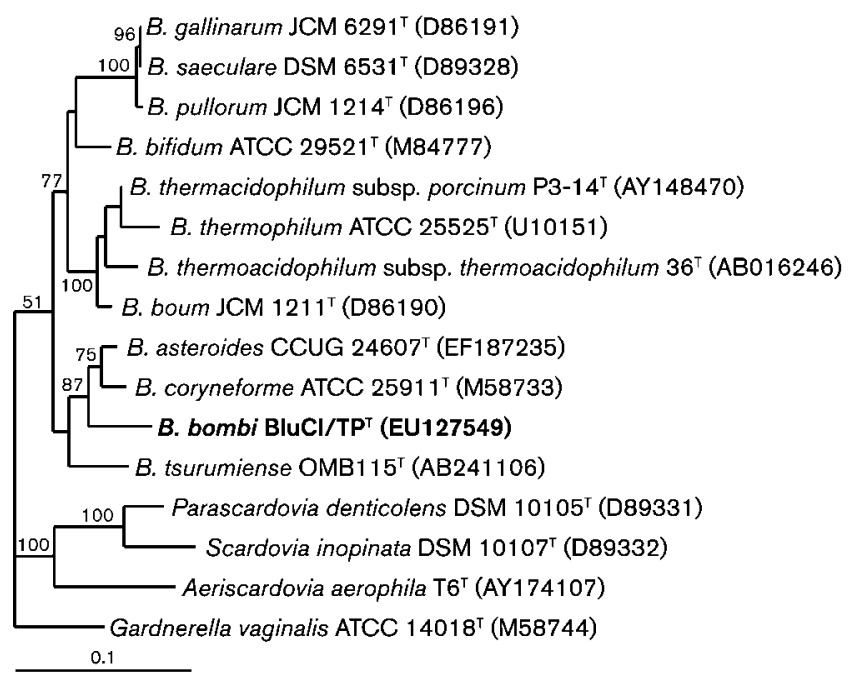

Fig. 1. Phylogenetic tree showing relationships of $16 \mathrm{~S}$ rRNA gene sequences of isolate BluCl/TP ${ }^{\top}$ and species of Bifidobacterium and related genera. Bar, 1 substitution per 100 nucleotides. The tree was constructed using neighbour-joining analysis of a distance matrix obtained from a multiple-sequence alignment in a model of sequence evolution. Gardnerella vaginalis ATCC $14018^{\top}$ was used as the outgroup sequence. 


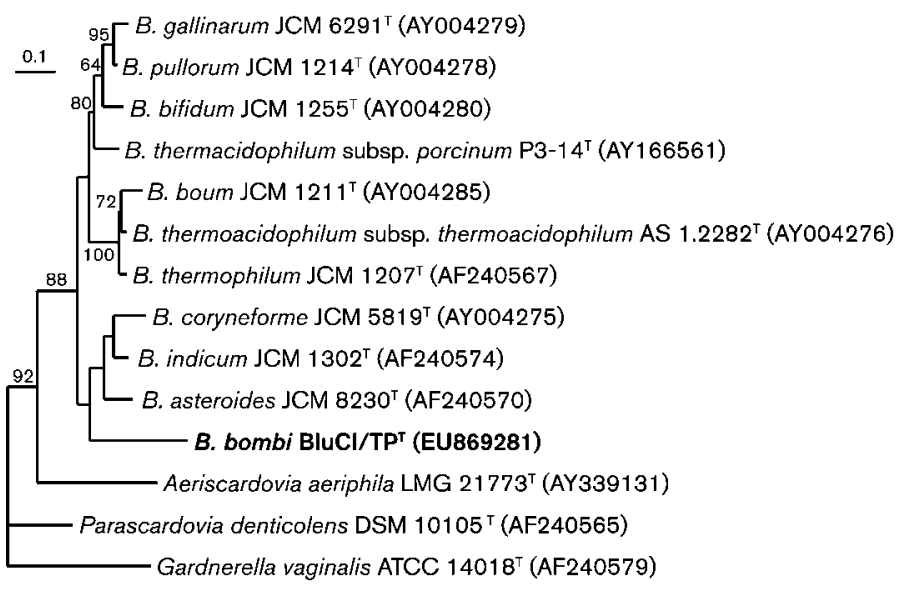

Fig. 2. Phylogenetic tree showing relationships of $h s p 60$ gene sequences of isolate $\mathrm{BluCl} / \mathrm{TP}^{\top}$ and species of Bifidobacterium and related genera. Bar, 1 substitution per 100 nucleotides. See legend to Fig. 1 for further details. highest $h$ sp60 gene sequence similarity of isolate $\mathrm{BluCI} / \mathrm{TP}^{\mathrm{T}}$ was to $B$. asteroides JCM $8230^{\mathrm{T}}(82 \%)$.

Bifidobacteria degrade hexoses via the fructose-6-phosphate phosphoketolase pathway. The key enzyme in this pathway is fructose-6-phosphate phosphoketolase. The enzyme is considered a taxonomic marker for identification of the genus Bifidobacterium (Biavati \& Mattarelli, 2006). The novel strains produced fructose-6-phosphate phosphoketolase (data not shown).

Substrate utilization (Table 1) and enzyme production by the isolates were tested with API $50 \mathrm{CH}$ and Rapid ID 32 test kits (bioMérieux). None of the isolates produced catalase, urease or indole. All strains utilized glucose, ribose, aesculin, salicin, arbutin and gentiobiose. The isolates produced $\beta$-galactosidase, $\alpha$ - and $\beta$-glucosidases, proline arylamidase, arginine arylamidase, phenylalanine arylamidase, leucine arylamidase, tyrosine arylamidase, histidine arylamidase and serine arylamidase. Glycerol, erythritol, arabinose, D- and L-xylose, galactose, sorbose, rhamnose, dulcitol, inositol, mannitol, sorbitol, cellobiose, maltose, lactose, inulin, glycogen and turanose were not utilized. The novel strains utilized mannose and melibiose and produced $\alpha$-galactosidase. All growth parameters are in good agreement with the descriptions of Bifidobacterium species and related genera (Jian \& Dong, 2002; Simpson et al., 2004).

Fermentation products (short-chain fatty acids) were analysed by GLC. After dilution and centrifugation, the short-chain fatty acid sample was ultrafiltered, transferred to $2 \mathrm{ml}$ vials and analysed on a gas chromatography capillary column with FID detector. Hydrogen was used as the carrier gas.

All strains tested fermented sugars to acetate and lactate (Table 2). Production of acetate and lactate was compared between the novel strains and bifidobacteria from the honeybee digestive tract. These bacteria, $B$. asteroides, $B$. coryneforme and $B$. indicum, are taxonomically distinct from other bifidobacteria (Sakata et al., 2006; Jian et al., 2001). Production of both lactate and acetate was similar to
B. asteroides, with the acetate/lactate ratio close to 3.3. No production of formate was observed in cultures of strain $\mathrm{BluCI} / \mathrm{TP}^{\mathrm{T}}$.

Cellular fatty acid profiles have been used previously to establish taxonomic relationships among anaerobic bacteria (Moore, 1994) and have also proved useful in the classification of Gram-positive bacteria (Van Den Velde et al., 2006). Cellular fatty acids were determined by GLC. Preparation of FAMEs by saponification, methylation and extraction into hexane and sample cleanup followed the procedure of Moore (1994). Methyl esters were analysed on a $100 \mathrm{~m} \mathrm{SP-2560}$ column using an Agilent GC 6890N chromatograph equipped with FID detector and Chromatopac C-R6A for data processing. A calibration standard (Supelco 37 component FAME mix) was used for identification of fatty acids and equivalent chain lengths were calculated for unknown peaks (Moore, 1994). Relative concentrations (\%, w/v) of individual fatty acids were calculated.

The fatty acid profile of cultures of isolate BluCI/TP contained small proportions of branched-chain fatty acids. The dominant fatty acids were oleic $\left(\mathrm{C}_{18: 1} ; 7.49 \%\right)$ and arachidic $\left(\mathrm{C}_{20: 0} ; 7.18 \%\right)$ acids. Isolate $\mathrm{BluCI} / \mathrm{TP}^{\mathrm{T}}$ contained a relatively high level of linoleic acid $\left(\mathrm{C}_{18}: 2 ; 7.34 \%\right)$. Heneicosanoic acid $\left(\mathrm{C}_{21: 0}\right)$ was not present. Four other fatty acids were present: palmitic $\left(\mathrm{C}_{16: 0} ; 7.14 \%\right)$, stearic $\left(\mathrm{C}_{18: 0} ; 5.91 \%\right)$, behenic $\left(\mathrm{C}_{22: 0} ; 5.87 \%\right)$ and tricosanoic $\left(\mathrm{C}_{23: 0} ; 5.38 \%\right)$ acids. The content of odd-numbered fatty

Table 2. Fermentation products of insect bifidobacteria grown on glucose in TPY medium

\begin{tabular}{|lccc|}
\hline Strain & $\begin{array}{c}\text { Acetate } \\
(\mathbf{m M})\end{array}$ & $\begin{array}{c}\text { Lactate } \\
(\mathbf{m M})\end{array}$ & Ratio \\
\hline $\begin{array}{l}\text { B. asteroides DSM 20089 } \\
\text { B. } \text { coryneforme DSM }^{\mathrm{T}}\end{array}$ & 45.0 & 13.6 & 3.3 \\
$\quad$ 20216 & 45.0 & 4.9 & 9.3 \\
B. indicum DSM 20214 $^{\mathrm{T}}$ & 46.0 & & \\
BluCI/TP & 59.0 & 17.0 & 6.7 \\
& & & \\
\hline
\end{tabular}


acids was high $(41.2 \%, \mathrm{w} / \mathrm{v})$. Increased content of unsaturated fatty acids corresponded with the lower optimal temperature for growth of isolate $\mathrm{BluCI} / \mathrm{TP}^{\mathrm{T}}$ (Suutari \& Laakso, 1994).

Morphological properties were examined by scanning electron microscopy. Samples were fixed with $3 \%(\mathrm{w} / \mathrm{v})$ glutaraldehyde in cacodylate buffer, $\mathrm{pH}$ 7.2, washed with a cacodylate buffer and allowed to settle for $48 \mathrm{~h}$ at $4{ }^{\circ} \mathrm{C}$ onto an SPI-pore filter $(0.2 \mu \mathrm{m})$ treated with poly-L-lysine (Sanders et al., 1975). The samples were dehydrated in an alcohol series followed by absolute acetone and dried in a critical-point device (Balzers 010). Alternatively, fixed and dehydrated clusters of aggregated bacterial cells were mounted onto aluminium stubs. Finally, all samples were sputter-coated with gold in a Polaron sputter-coater (Series $11 \mathrm{HD})$ and examined in a Philips CM12/STEM electron microscope at $80 \mathrm{kV}$ or in an Aquasem scanning electron microscope (TESCAN) at $15 \mathrm{kV}$. All recorded images were digitally processed in Analysis 3.2 software (Olympus Soft Imaging Solutions).

We propose the novel species Bifidobacterium bombi sp. nov. for the strains from the bumblebee digestive tract because of their unique metabolic and morphological properties, supported by distinctive lipid composition and gene sequences.

\section{Description of Bifidobacterium bombi sp. nov.}

Bifidobacterium bombi (bom'bi. L. n. bombus a boom, a deep hollow noise, buzzing, also the zoological genus name of the bumblebee; N.L. gen. n. bombi of Bombus, of a bumblebee).

Cells are Gram-positive-staining, catalase- and oxidasenegative, non-motile, non-spore-forming, short and irregularly shaped rods $(0.4-0.5 \mu \mathrm{m}$ wide and $0.9-1.1 \mu \mathrm{m}$ long). In culture, the appearance resembles dividing bacilliform cells, frequently forming filaments, with irregular contractions along the cells and bifurcations (Fig. 3). Strictly anaerobic. Colonies on TPY agar under anaerobic conditions are white, circular and low convex with sharp, undulate edges. Colonies reach $1.0-1.7 \mathrm{~mm}$ in diameter after 3 days of incubation. Mannose and melibiose are utilized. Good growth occurs at $10-37{ }^{\circ} \mathrm{C}$ (optimum $30{ }^{\circ} \mathrm{C}$; maximum $37^{\circ} \mathrm{C}$ ); very limited growth at $47{ }^{\circ} \mathrm{C}$. Minimal initial $\mathrm{pH}$ for growth is 4.5 . The DNA $\mathrm{G}+\mathrm{C}$ content of the type strain is $47.3 \mathrm{~mol} \%$.

The type strain is BluCI/TP ${ }^{\mathrm{T}}$ (=ATCC BAA- $1567^{\mathrm{T}}=\mathrm{DSM}$ $19703^{T}$ ), isolated from the digestive tract contents of Bombus lucorum from central Bohemia, Czech Republic.

\section{Acknowledgements}

This work was supported by the Grant Agency of the Czech Academy of Sciences (project no. GA AV ČR 1QS500200572), IRP IAPG (no. AV0Z50450515), IRP IMB (no. AV0Z50200510) and grant no. MSM 6046070901 of the Grant Agency of the Ministry of Education, Youth

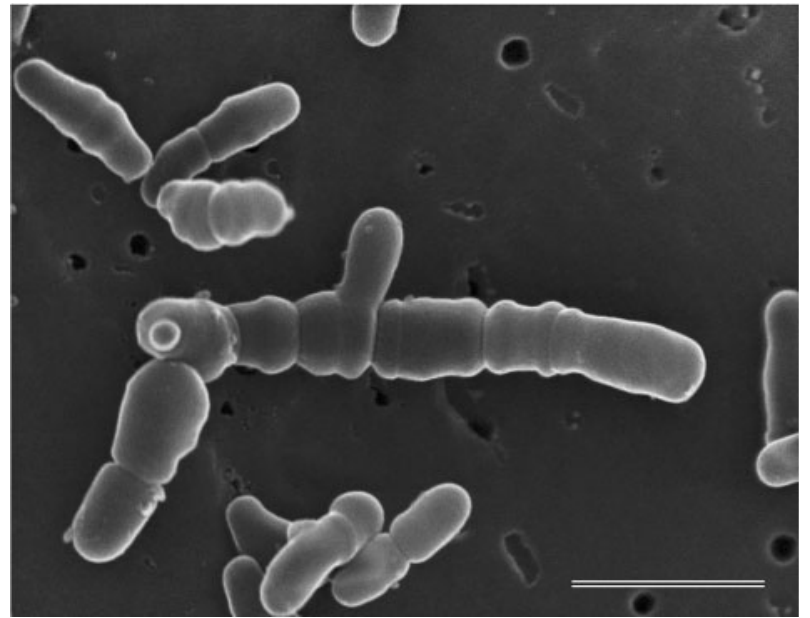

Fig. 3. Scanning electron photomicrograph of cells of strain $\mathrm{BluCl} / \mathrm{TP}^{\top}$ showing occasional bifurcations and irregular constrictions. Bar, $1 \mu \mathrm{m}$.

and Sports of Czech Republic. We appreciate the help of Dr J. P. Euzéby (École Nationale Vétérinaire, Toulouse) with nomenclature.

\section{References}

Barcenilla, A., Pryde, S. E., Martin, J. C., Duncan, S. H., Stewart, C. S., Henderson, C. \& Flint, H. J. (2000). Phylogenetic relationship of butyrate-producing bacteria from the human gut. Appl Environ Microbiol 66, 1654-1661.

Biavati, B. \& Mattarelli, P. (2006). The family Bifidobacteriaceae. In The Prokaryotes: a Handbook on the Biology of Bacteria, 3rd edn, vol. 3, pp. 322-382. Edited by M. Dworkin, S. Falkow, E. Rosenberg, K. H. Schleifer \& E. Stackebrandt. New York: Springer.

Felis, G. E. \& Dellaglio, F. (2007). Taxonomy of lactobacilli and bifidobacteria. Curr Issues Intest Microbiol 8, 44-61.

Felsenstein, J. (1985). Confidence limits on phylogenies: an approach using the bootstrap. Evolution 39, 783-791.

Forster, R. J., Teather, R. M., Gong, J. \& Deng, S. J. (1996). 16 S rRNA analysis of Butyrivibrio fibrisolvens: phylogenetic position and relation to butyrate producing anaerobic bacteria from the rumen of a shorttailed deer. Lett Appl Microbiol 23, 218-222.

Gilliam, M. (1997). Identification and roles of non-pathogenic microflora associated with honeybees. FEMS Microbiol Lett 155, 1-10.

Gregg, K., Cooper, C. L., Schafer, D. J., Sharpe, H., Beard, C. E., Allen, G. \& Xu, J. (1994). Detoxification of the plant toxin fluoroacetate by a genetically modified rumen bacterium. Biotechnology 12, 1361-1365.

Hall, T. A. (1999). BioEdit: a user-friendly biological sequence alignment editor and analysis program for Windows 95/98/NT. Nucleic Acids Symp Ser 41, 95-98.

Huys, G., Vancanneyt, M., D'Haene, K., Falsen, E., Wauters, G. \& Vandamme, P. (2007). Alloscardovia omnicolens gen. nov., sp nov., from human clinical samples. Int J Syst Evol Microbiol 57, 1442-1446.

Jian, W. \& Dong, X. (2002). Transfer of Bifidobacterium inopinatum and Bifidobacterium denticolens to Scardovia inopinata gen. nov., 
comb. nov., and Parascardovia denticolens gen. nov., comb. nov., respectively. Int J Syst Evol Microbiol 52, 809-812.

Jian, W., Zhu, L. \& Dong, X. (2001). New approach to phylogenetic analysis of the genus Bifidobacterium based on partial HSP60 gene sequences. Int J Syst Evol Microbiol 51, 1633-1638.

Kačániová, M., Chlebo, R., Kopernický, M. \& Trakovická, A. (2004). Microflora of the honeybee gastrointestinal tract. Folia Microbiol (Praha) 49, 169-171.

Maidak, B. L., Larsen, N., McCaughey, M. J., Overbeek, R., Olsen, G. J., Fogel, K., Blandy, J. \& Woese, C. R. (1994). The Ribosomal Database Project. Nucleic Acids Res 22, 3485-3487.

Mesbah, M., Premachandran, U. \& Whitman, W. B. (1989). Precise measurement of the $\mathrm{G}+\mathrm{C}$ content of deoxyribonucleic acid by highperformance liquid chromatography. Int J Syst Bacteriol 39, 159-167.

Mohr, K. I. \& Tebbe, C. C. (2006). Diversity and phylotype consistency of bacteria in the guts of three bee species (Apoidea) at an oilseed rape field. Environ Microbiol 8, 258-272.

Moore, W. E. C. (1994). Comparative distribution and taxonomic value of cellular fatty acids in thirty-three genera of anaerobic gramnegative bacilli. Int J Syst Bacteriol 44, 338-347.

Posada, D. \& Crandall, K. A. (1998). Modeltest: testing the model of DNA substitution. Bioinformatics 14, 817-818.

Rada, V. \& Petr, J. (2000). A new selective medium for the isolation of glucose nonfermenting bifidobacteria from hen caeca. J Microbiol Methods 43, 127-132.

Sakata, S., Ryu, C. S., Kitahara, M., Sakamoto, M., Hayashi, H., Fukuyama, M. \& Benno, Y. (2006). Characterization of the genus Bifidobacterium by automated ribotyping and 16S rRNA gene sequences. Microbiol Immunol 50, 1-10.
Sambrook, J., Fritsch, E. F. \& Maniatis, T. (1989). Molecular Cloning: a Laboratory Manual, 2nd edn. Cold Spring Harbor, NY: Cold Spring Harbor Laboratory.

Sanders, S. K., Alexander, E. L. \& Braylan, R. C. (1975). A high-yield technique for preparing cells fixed in suspension for scanning electron microscopy. J Cell Biol 67, 476-480.

Simpson, P. J., Ross, R. P., Fitzgerald, G. F. \& Stanton, C. (2004). Bifidobacterium psychraerophilum sp. nov. and Aeriscardovia aeriphila gen. nov., sp. nov., isolated from a porcine caecum. Int J Syst Evol Microbiol 54, 401-406.

Suutari, M. \& Laakso, S. (1994). Microbial fatty-acids and thermal adaptation. Crit Rev Microbiol 20, 285-328.

Swofford, D. L. (2003). PAUP: phylogenetic analysis using parsimony (and other methods), version 4. Sunderland, MA: Sinauer Associates.

Tavaré, S. (1986). Some probabilistic and statistical problems in the analysis of DNA sequences. In Some Mathematical Questions in Biology: DNA Sequence Analysis (Lectures on Mathematics in the Life Sciences, vol. 17), pp. 57-86. Edited by R. M. Miura. Providence, RI: American Mathematical Society.

Thompson, J. D., Higgins, D. G. \& Gibson, T. J. (1994). CLUSTAL W: improving the sensitivity of progressive multiple sequence alignment through sequence weighting, position-specific gap penalties and weight matrix choice. Nucleic Acids Res 22, 4673-4680.

Van Den Velde, S., Lagrou, K., Desmet, K., Wauters, G. \& Verhaegen, J. (2006). Species identification of corynebacteria by cellular fatty acid analysis. Diagn Microbiol Infect Dis 54, 99-104.

Weisburg, W. G., Barns, S. M., Pelletier, D. A. \& Lane, D. J. (1991). 16S ribosomal DNA amplification for phylogenetic study. J Bacteriol 173, 697-703. 